\title{
Restructuring Efforts in the Turkish Agriculture, Availability of Resources and Developments in Rural: An Overall Analysis from 2001 to 2016
}

\author{
Nizamettin ERBAȘ ${ }^{1 *}$
}

\begin{abstract}
In this research, since transition to its restructuring, developments in agricultural sector were analysed with outlines. Because of the fact that this transition was in 2001, 2001 year was regarded as year of start. The reasons for the transition have been to increase the farmer registration system, subsidize the agricultural sector, and sustain the importance of the agriculture for economy. In the study, 2001-2016 period were examined, and it was observed that there were important developments in rural in 16 years. These were decrease of the agricultural areas, decline of the field farming, too much migration mobility from rural towards urban, and significantly diminishing of the rural population and the number of agricultural enterprises. Because agricultural lands were not sufficiently utilized, some crops' production potential dropped off. Even if animal products' production increased, that was not enough to satisfy the domestic demand and to export. Thus, it was determined that most of agricultural products was imported. By regression analysis, agricultural area size was estimated and it was seen that decrease of the agricultural areas could continue in the following years. In the study, some constructive proposals were also brought forward regarding improvement the agriculture and the rurals.
\end{abstract}

Keywords: Agricultural lands' usage, availability of resources, regression analysis, restructuring in agricultural sector, rural sector

\section{Türk Tarımında Yeniden Yapılanma Çalışmaları, Kaynakların Kullanılabilirliği ve Kırsal Kesimdeki Gelişmeler: 2001'den 2016’ya Kadar Kapsamlı Bir Analiz}

ÖZET: Bu çalışmada, tarımda yeniden yapılanma sürecinde tarım kesiminde görülen tüm gelişmeler ana hatlarıyla ele alınmıştır. Yeniden yapılanmaya geçiş nedeniyle, 2001 yılı çalışmada baz olarak alınmıştır. Geçişin nedenleri, çiftçi kayıt sisteminin oluşturulması, tarımın sübvanse edilmesi ve tarımın ekonomideki ağırlı̆̆ının korunmasıdır. Çalışmada, 2001-2016 dönemi incelenmiş ve 16 yılda kırsal kesimde önemli gelişmelerin olduğu görülmüştür. Tarım yapılabilir alanlar azalmış, tarla tarımı gerilemiş, kırsal kesimden kentlere göç hareketliliŭi hızlanmış ve kırsal nüfus ile tarımsal işletme sayısında önemli ölçüde düşüş yaşanmıştır. Tarım arazileri yeterince kullanılmadığından, bazı bitkisel ürünlerin üretim potansiyeli azalmıştır. Hayvansal üretimde artış görülse de, bu artış iç talebi karşılamak ve dışsatım yapmak için yeterli olmamıştır. Böylece, pek çok tarım ürününün ithal edildiği belirlenmiştir. Regresyon analizi ile gelecekte tarım alanı miktarı tahmin edilmiş ve tarım alanlarındaki düşüşün önümüzdeki yıllarda da devam edeceği görülmüştür. Çalışmada, ayrıca, tarım ve kırsal alanların iyileştirilmesine ilişkin bazı yapıcı öneriler de sunulmuştur.

Anahtar Kelimeler: Tarım arazilerinin kullanımı, kaynakların kullanılabilirliği, regresyon analizi, tarımda yeniden yapılanma, kırsal kesim

\footnotetext{
${ }^{1}$ Nizamettin ERBAŞ (Orcid ID: 0000-0002-6379-3023), Yozgat Bozok Üniversitesi, Sosyal Bilimler MYO, Yönetim ve Organizasyon Bölümü, Yozgat, Türkiye

*Sorumlu Yazar / Corresponding Author: e-mail: nizamettin.erbas@bozok.edu.tr
}

Geliş tarihi / Received: 21-06-2019

Kabul tarihi / Accepted: 15-10-2019 


\section{INTRODUCTION}

The history of agriculture dates back 10000 years. Human being who was sustaining his life with hunting at that time has discovered the agriculture after a certain period. Later, they have formed societies thanks to agriculture, and founded states. Thus, agriculture has developed as an important process in the socioeconomic and cultural development in addition to people' nourishment, too. In this context, the agricultural sector should be seen as one of the fundamental sectors in the economic and social development of the countries (Doğan et all., 2015; Anonymous, 2018r).

Therefore, it is not possible for another sector to take the place of the agricultural sector. The agriculture constitutes the main field of employment of the majority of poor people in the entire world (Meijerink and Roza, 2007). In this context, as agriculture has an enormous influence on the whole society, it continues to be regarded as a vital component (Vasile et al., 2017).

The agriculture is also necessary for industrialization. It is sole way for the industrialization. For, most of the industries provide the raw material from agriculture. But, role of the agricultural sector in nations industrialized is slightly different from developing nations (T1mmer, 1988). The important of the manufacturing industry for industrialized countries is a bit more than other countries.

Importance of the agriculture is indisputable for Turkey. Natural conditions, geographic and land structure of Turkey are very convenient for the agriculture. It is farmed in at least half of surface area. It has a significant share in general employment. According to data 2016, 19.5\% of total employment was in the agricultural sector. Its share in total foreign trade was $8.3 \%$ and in gross domestic product was $7.4 \%$ (Anonymous, 2018a). Turkey has wide and fertile agricultural and pasture lands. That's why, it isn't possible for the agriculture to be abandoned or be neglected. Geopolitical and economic structure of Turkey gains an important advantage to agriculture.

A communique about the agricultural sector was issued by the Ministry of Agriculture and Forest on 21 June 2001 (Anonymous, 2018f). In this communique, it was aimed to constitute the farmer registration system in the rural and to subsidize directly the farmers who make agricultural production. 2588666 farmers were registered in 2002 following publishing of the communique. But, the number of registered farmers decreased in following years and happened 2267176 in 2016 (Anonymous, 2018s).

Since restructuring of the agriculture, there have happened significant developments in sector. In order to be able to see whether these developments in the agricultural sector have reached their goal, the data in this period should be known and followed (Yilmaz et al., 2006). In this study, developments for period 2001-2016 were analysed.

This study, which is original, is important in terms of shedding light on future studies and making a decision for agricultural investments.

\section{MATERIALS AND METHODS}

In this study, secondary data were used. Those were data of the government agencies (the Turkish Statistical Institute, the Ministry of Agriculture and Forest, and Food and Agriculture Organization-FAO).

In the study, the data for period 2001-2016 were examined with a view to determine availability of resources, and developments in agricultural sector. In the same period, total agricultural area and its usage, the number of rural population and agricultural enterprise, agriculture's share in total employment, agriculture's share in total gross domestic product, agriculture's share in total foreign trade, developments in vegetal product' production and animal products' production were revealed. 
The change of the production amount was examined, and its effect on foreign trade was discussed. In consequence of these developments, it was suggested what to do. In the study, also some agricultural data of Turkey and the Netherland were examined, and compared.

For analysis of data, it was benefited from Microsoft Excel Program. The data were arranged in accordance with the purpose, and tables and figures were consisted, and commented. They were compared by using descriptive statistics. Total agricultural area of following years was calculated and estimated by regression model. Regression model was given in Equality 1, 2, 3 (Gürsakal, 2000; Şimşek, 2002):

$$
\begin{aligned}
& Y=a+b X \\
& \sum Y=n \cdot a+b \cdot \sum X \\
& \sum X Y=a \cdot \sum X+b \cdot \sum X^{2}
\end{aligned}
$$

In regression model, $\mathrm{a}$ and $\mathrm{b}$ shows the regression coefficient, $X$ the independent variable (year) and $\mathrm{Y}$ the dependent variable (total agricultural area).

\section{RESULTS AND DISCUSSION}

\section{Developments in Agricultural Area}

Agricultural land is one of the five basic agricultural production factors, and is the environments which production is made on itself (Aç1l ve Demirci, 1984). Since it is the fundamental factor in the supply of nutrient requirement, it has to be protected.

According to data 2001, total agricultural area of Turkey was 40967475 hectare, and 23740 022 hectare of it was cultivated (Anonymous, 2018b). 22830717 hectare of the area cultivated was the field land. In the last 15 years, total agricultural area was decreased by $6.31 \%$, total cultivated land by $13.90 \%$ and total field land by $14.04 \%$ (Table 1). In examined period, it is seen there was increase in area that was cultivated fruit only. The area that was cultivated fruit increased by $38.78 \%$. Whereas, total field land decreased by $14.04 \%$, and the area that was grown vegetable by $11.03 \%$. These ratios show that there was a turning towards fruit agriculture from field agriculture.

Table 1. Agricultural land and its usage

\begin{tabular}{lrrr}
\hline & $\mathbf{2 0 0 1}$ & $\mathbf{2 0 1 6}$ & Index \\
\hline Agricultural area & (hectare) & (hectare) & (2001=100) \\
\hline Sowed & 17917083 & 15574372 & 86.92 \\
Fallow & 4913634 & 4049998 & 82.42 \\
Total field & 22.830717 & 19.624370 & 85.96 \\
Vegetable & 909305 & 808986 & 88.97 \\
Cultivated & 23740.022 & 20433356 & 86.07 \\
Fruit & 2085453 & 2894216 & 138.78 \\
Vineyard & 525000 & 435000 & 82.85 \\
Total fruit and vineyard & 2610453 & 3329216 & 127.53 \\
Cultivat.+(fruit and vineyard) & 26350475 & 23762572 & 90.18 \\
Meadow and pasture & 14617000 & 14617000 & 100.00 \\
Total agricultural area & 40967475 & 38379572 & 93.68 \\
Total surface area & & 78356200 & \\
\hline
\end{tabular}

Source: TUIK

In Table 2, total agricultural area of Turkey for period 2001-2016 was given (Anonymous, 2018c). When Table 2 examined, it is seen that total agricultural area decreased by $6.31 \% *$ in the last 15 years. According to the regression analysis, it is expected that decline of agricultural areas can continue in the following years. The consequences of this decline for Turkey will not be good: 
Agricultural production will have reduced, and Turkey will have been a dependent country on foreign countries in terms of agricultural products. Employment will have decreased, unemployment will have increased, and migration from rural to urban will have been accelerated. In short, the impacts of this decline on Turkey's economy will have been negative.

Table 2. Agricultural area of Turkey for period 2001-2016

\begin{tabular}{|c|c|c|c|c|}
\hline n (year) & $\mathrm{x}$ & \multicolumn{3}{|c|}{ y (1000 hectare) } \\
\hline 2001 & 0 & 0 & 40967 & 0 \\
\hline 2002 & 1 & 1 & 41196 & 41196 \\
\hline 2003 & 2 & 4 & 40644 & 81288 \\
\hline 2004 & 3 & 9 & 41210 & 123630 \\
\hline 2005 & 4 & 16 & 41223 & 164892 \\
\hline 2006 & 5 & 25 & 40493 & 202465 \\
\hline 2007 & 6 & 36 & 39504 & 237024 \\
\hline 2008 & 7 & 49 & 39122 & 273854 \\
\hline 2009 & 8 & 64 & 38912 & 311296 \\
\hline 2010 & 9 & 81 & 39011 & 351099 \\
\hline 2011 & 10 & 100 & 38231 & 382310 \\
\hline 2012 & 11 & 121 & 38399 & 422389 \\
\hline 2013 & 12 & 144 & 38423 & 461076 \\
\hline 2014 & 13 & 169 & 38558 & 501254 \\
\hline 2015 & 14 & 196 & 38551 & 539714 \\
\hline 2016 & 15 & 225 & 38380 & 575700 \\
\hline Total & 120 & 1.240 & 632824 & 4669187 \\
\hline
\end{tabular}

In the research, total agricultural area of Turkey in the following years was estimated by regression model (by using the data in Table 2). In the analysis, it was accepted that other conditions remained stable in other words, there was no change in existing agricultural policies and agricultural conditions. (X) was independent variable (year) and (Y) also dependent variable (agricultural area). Decrease in the agricultural area from year to year showed that there was a nonlinear relationship between variables (Figure 1).

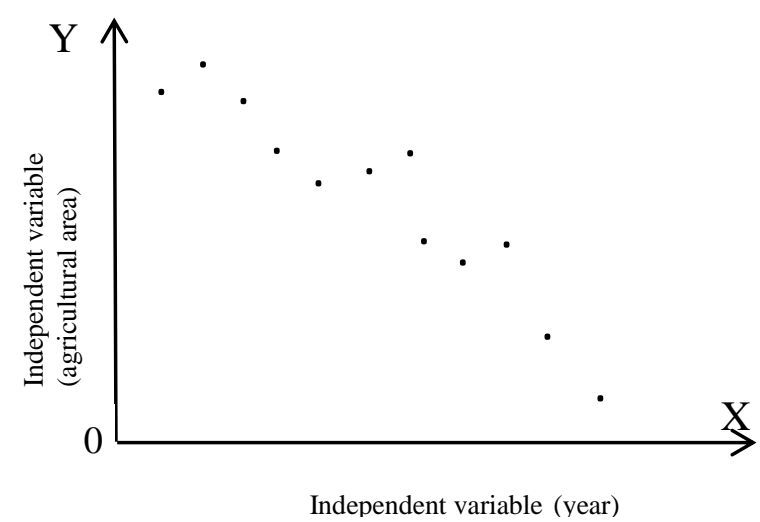

Figure 1. Relationship' case between variables

According to this, when taken into consideration $(Y=a+b X)$ function, 15 years later, in other words, in 2031, it was guessed that the total agricultural area of Turkey will have been 34467 thousand hectare.

For 2031 year; 


$$
\begin{aligned}
Y & =a+b X \\
Y & =41.247+(-226 \cdot 30) \\
& =41.247-6.780 \\
& =34467 \text { thousand hectare. }
\end{aligned}
$$

\section{Developments in the Number of Rural Population and Agricultural Enterprises}

Since the creator of economic life is human, the relationship between population and economy is quite high (Aç1l ve Demirci, 1984). On the one hand while the population creates demand for goods and services, on the other hand it provides labor supply, which is one of the main production factors (Rehber and Çetin, 1998). In this context, the population is an important dynamic in terms of economic development.

In Table 3, rural and urban population ratios were given for period 2000-2016. In the study, since the data of 2001 year couldn't be accessed to, year of start was based on 2000 year. When table examined, in the 16-year period, rural population seems to have decreased significantly. Because, while rural population decreased by $74.19 \%$, urban population increased by $67.41 \%$ (Anonymous, 2018d). Of course, on this decrease, it can be stated there was also effective that "the administrative fields of metropolitan municipalities with the law no. 6360 adopted in 2012 were considered as urban areas completely" (Anonymous, 2018e).

Rapid decrease of the rural population is closely associated with rural migrations. Low income in the rural and educational opportunities in citied speed the migrations towards urban from rural up (Y1lmaz, 2015). Basically, rural migration is an economic decision (Cengiz and Baydur, 2010). Rural migrations lead to loss of qualified labor force in rural, and surplus of labor force and an unplanned urbanization in cities, too.

Table 3. Urban and rural population

\begin{tabular}{lccc} 
& 2000 & 2016 & Index \\
\cline { 2 - 3 } Population & (person) & (person) & $(2000=100)$ \\
\hline Rural & 23797653 & 6143123 & 25.81 \\
Urban & 44006274 & 73671748 & 167.41 \\
\hline Total & 67803927 & 79814871 & 117.71 \\
\hline Source: TUIK & & &
\end{tabular}

In Table 4, the number of agricultural enterprises was given in Turkey, In the study, since the data of 2001 year couldn't be accessed to, year of start was based on 2002 year. Thus, while the number of total agricultural enterprise of Turkey was 2588666 in 2002, in the last 14 years, it decreased by $12.42 \%$, and it happened 2267176 (Table 4). In the same period, rural population decreased by $74.19 \%$ (Anonymous, 2018g). This was also a self-evident indication of transformation towards urban population of the rural population. In study, average enterprise size of Turkey was determined as 86 decare.

Table 4. The number of agricultural enterprises

\begin{tabular}{ccc}
\hline 2002 & 2016 & Index \\
\cline { 1 - 2 } (number) & (number) & $(2002=100)$ \\
\hline 2588666 & 2267176 & 87.58 \\
\hline
\end{tabular}

Source: The Ministry of Agriculture and Forestry 


\section{Agriculture's Share in Total Employment}

Employment is working of all production factors in an economy, and especially the labor force in working age (Çelik, 2015; Ünlüönen and Tayfun, 2005). In Turkey, the agricultural sector has an important share in total employment.

In Figure 2, agriculture's share in total employment was given. When Figure 2 was examined, it is seen that share of the agriculture in total employment decreased gradually. For instance, while share of the agriculture in total employment was $37.58 \%$ in 2001, it was $19.50 \%$ in 2016 (Anonymous, 2018h). Share of the agriculture in total employment decreased by $34.42 \%$ in the last 15 years.

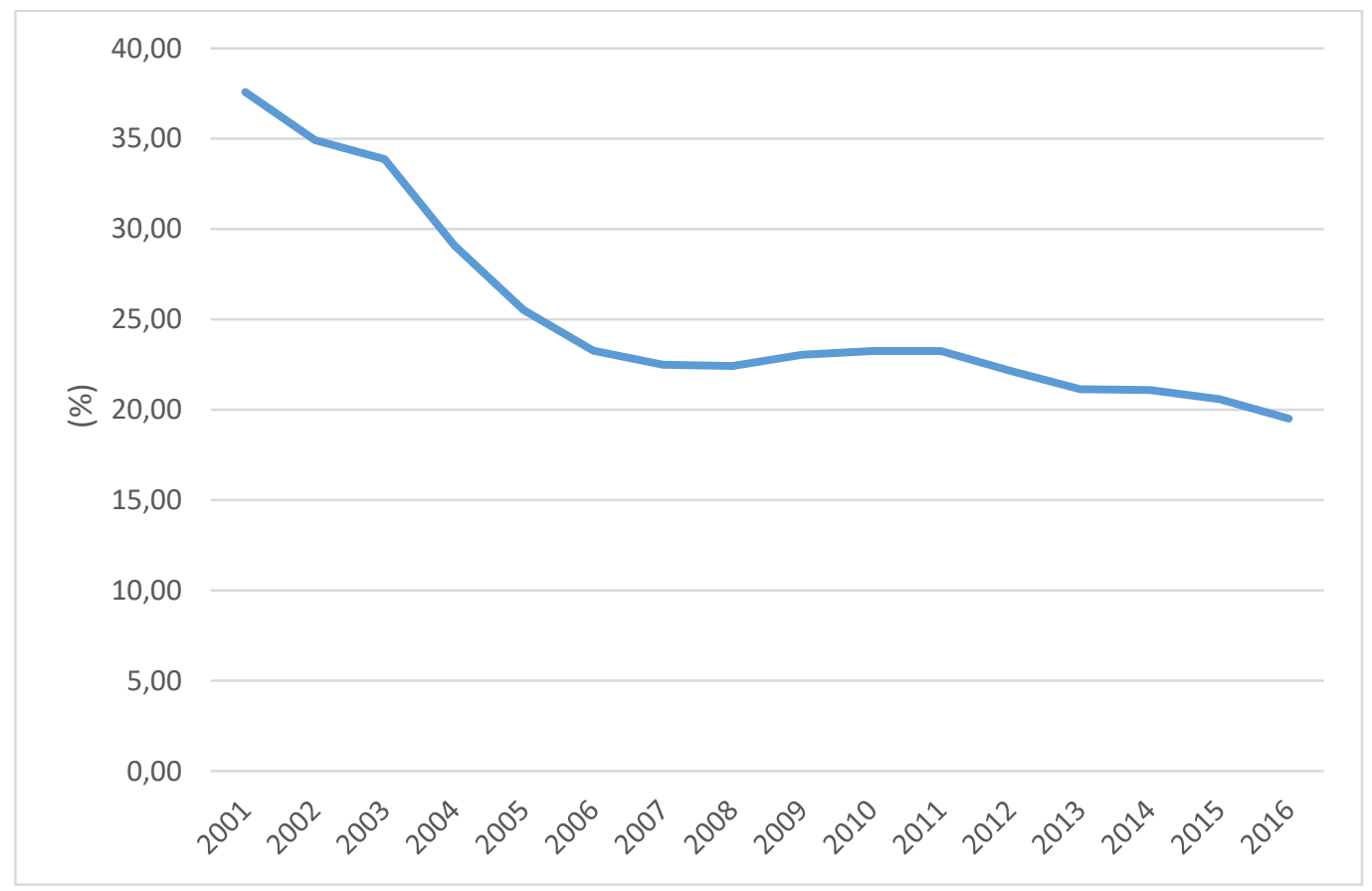

Figure 2. Agriculture's share in total employment

\section{Agriculture's Share in Total Gross Domestic Product}

Gross domestic product is sum value of final goods and services produced in a country in a year. Gross domestic product is fundamental criter to assess the performance of economy regarding goods and service production (Aç11, 1984; Ünlüönen and Tayfun, 2005).

Agriculture's share in total gross domestic product was given in Figure 3 with respect to years. When examined figure, it is seen even if income obtained from agricultural sector increased in the last 15 years, its share in total gross domestic product decreased. While income obtained from agricultural sector was 22736 million USD in 2001, it was 53276 million USD in 2016. But, while its share in total gross domestic product was $11.56 \%$ in 2001, it was $7.37 \%$ in 2016 (Anonymous, 20181). In other words, in the last 15 years, the share that the agriculture received in total gross domestic product was balanced between $11.56 \%$ and $7.37 \%$. Without forgetting Turkey is an agricultural country, it should be given consequence to the agricultural sector, and the share of agriculture in total gross domestic product should be increased. 


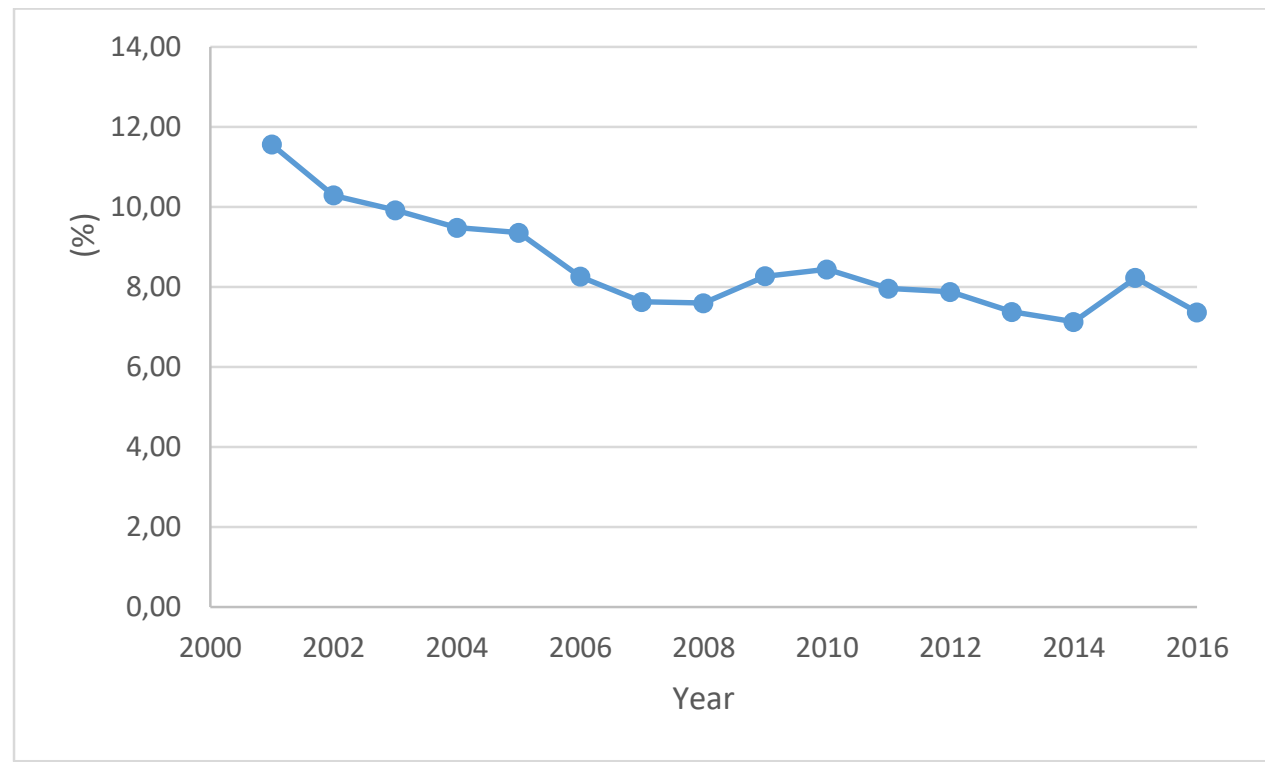

Figure 3. Agriculture's share in total gross domestic product

\section{Agriculture's Share in Total Foreign Trade}

Foreign trade is the goods, service and capital trade of a country with other countries (Arrkan, 1999). Foreign trade value is consists of the sum of the export and import values of a country in a given period.

In Turkey, in the last 15 years, while agriculture's share in total export decreased, its share in total import increased (Figure 4). For instance, in 2001, share of the agricultural sector in total import was $5.95 \%$ and its share in total export was $13.09 \%$. In 2016, they were $6.1 \%$ and $11.49 \%$. While agricultural import was 2464 million USD in 2001, it was 12111 million USD in 2016 (Anonymous, 20180̈j). In order to increase share of the agriculture in export, agricultural production should be increased, and new foreign markets created.

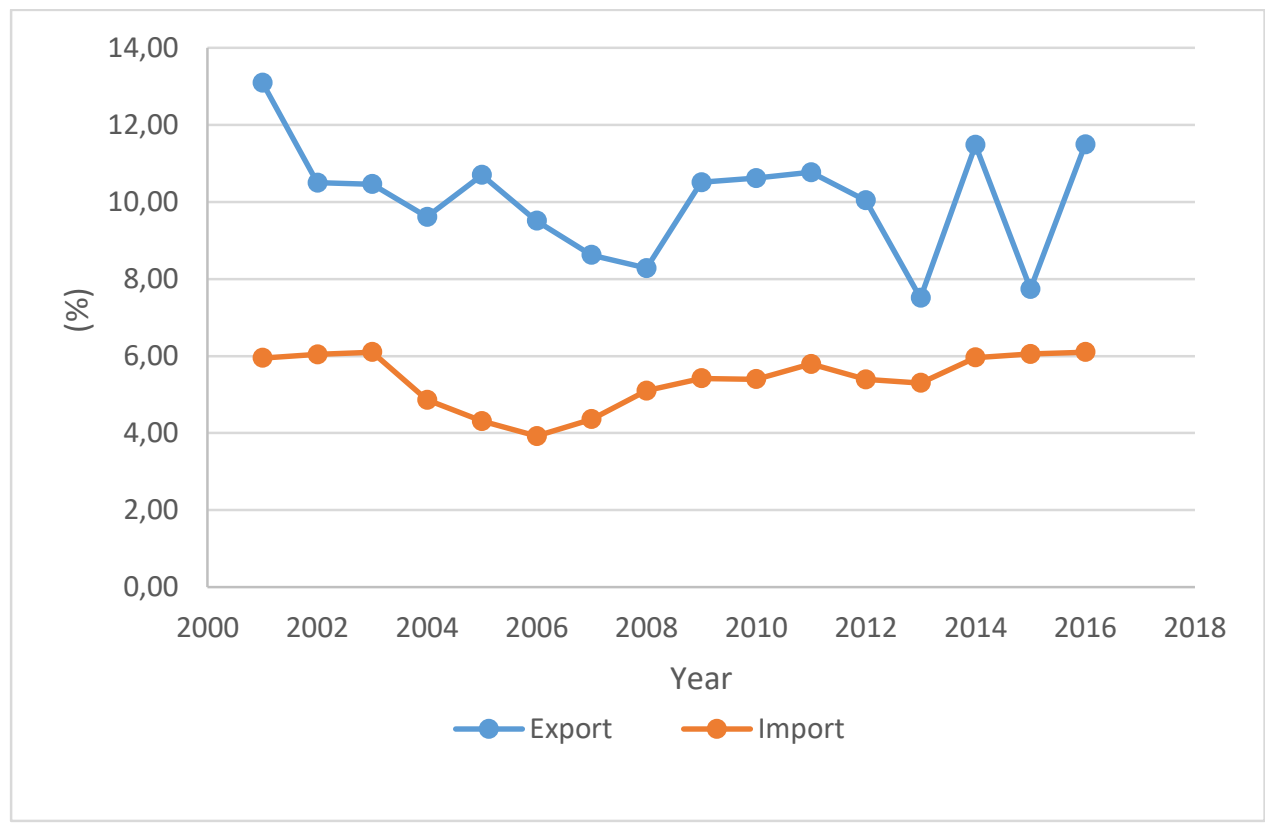

Figure 4. Agriculture's share in total foreign trade 


\section{Developments in Vegetal Product' Production}

In Table 5, production of some field crops and sowed land were given (Anonymous, 2018k). When the table was examined, in the last 15 years, it was seen that sowed field land and amount of production (especially legume plants) decreased. There was increase in forage plants' production. Naturally, this was a demonstration of turning towards animal husbandry from field farming. As long as there is no change in the agricultural policies, this turning towards is expected to continue in the future.

Table 5. Developments in production of some field crops

\begin{tabular}{|c|c|c|c|c|c|c|}
\hline Field crops & \multicolumn{2}{|c|}{2001} & \multicolumn{2}{|c|}{2016} & \multirow{2}{*}{$\begin{array}{c}\text { Index } \\
\text { Sowed }\end{array}$} & \multirow{2}{*}{$\frac{(2001=100)}{\text { Production }}$} \\
\hline CEREAL & $\begin{array}{c}\text { Sowed } \\
\text { (decare) }\end{array}$ & $\begin{array}{l}\text { Production } \\
\text { (tons) }\end{array}$ & $\begin{array}{c}\text { Sowed } \\
\text { (decare) }\end{array}$ & $\begin{array}{l}\text { Production } \\
\text { (tons) }\end{array}$ & & \\
\hline Wheat & 93500000 & 19000000 & 76719448 & 20600000 & 82.05 & 108.42 \\
\hline Barley & 36400000 & 7500.000 & 27400521 & 6700000 & 75.28 & 89.33 \\
\hline Rye & 1405000 & 220000 & 1146493 & 300000 & 81.60 & 136.36 \\
\hline Oat & 1500000 & 265000 & 994379 & 225000 & 66.29 & 84.91 \\
\hline Millet & 35000 & 6700 & 23869 & 5327 & 68.20 & 79.51 \\
\hline Meslin & 82000 & 11650 & 4100 & 615 & 5.00 & 5.28 \\
\hline Corn (grain) & 5500000 & 2200000 & 6800192 & 6400000 & 123.64 & 290.91 \\
\hline Paddy & 590000 & 360000 & 1160563 & 920000 & 196.70 & 255.55 \\
\hline \multicolumn{7}{|l|}{ TOBACCO } \\
\hline Raw tobacco & 1.957 .700 & 144.786 & 922.374 & 70.000 & 47.17 & 48.35 \\
\hline \multicolumn{7}{|l|}{ LEGUMES } \\
\hline Chickpea & 6450000 & 535000 & 3595289 & 455000 & 55.74 & 85.05 \\
\hline Beans (dry) & 1750000 & 225000 & 898197 & 235000 & 51.32 & 104.44 \\
\hline Lentil (green) & 700000 & 60000 & 167617 & 20000 & 23.94 & 33.33 \\
\hline Lentil (red) & 4000000 & 460000 & 2354743 & 345000 & 58.87 & 75.00 \\
\hline Kidney bean & 29000 & 2000 & 18079 & 1860 & 62.34 & 93.00 \\
\hline Vetch (grain) & 29000 & 3000 & 35921 & 3996 & 123.86 & 133.20 \\
\hline Broad bean & 190000 & 35000 & 27512 & 6280 & 14.48 & 17.94 \\
\hline Green pea & 12500 & 2700 & 10882 & 2919 & 87.06 & 108.11 \\
\hline \multicolumn{7}{|l|}{$\begin{array}{l}\text { INDUSTRY } \\
\text { PLANTS }\end{array}$} \\
\hline Sugar beet & 3587630 & 12632522 & 3224477 & 19465542 & 89.88 & 154.09 \\
\hline Potato & 2000000 & 5000000 & 1448572 & 4750000 & 72.43 & 95.00 \\
\hline \multicolumn{7}{|l|}{ OİL PLANTS } \\
\hline Sunflower (oil) & 5100000 & 650000 & 6167800 & 1500000 & 120.94 & 230.77 \\
\hline Cotton seed & 6846650 & 1353888 & 4160098 & 1260000 & 60.76 & 93.06 \\
\hline \multicolumn{7}{|c|}{ FORAGE PLANTS } \\
\hline Clover(green) & 2490000 & 1830000 & 6501107 & 15714381 & 261.09 & 858.71 \\
\hline Trefoil (green) & 1055000 & 203000 & 1936940 & 1982047 & 183.60 & 976.38 \\
\hline Vetch (grain) & 2400000 & 127000 & 526762 & 66987 & 21.95 & 414.53 \\
\hline Mangel & 31500 & 150000 & 23408 & 111974 & 74.31 & 74.65 \\
\hline \multicolumn{7}{|l|}{$\begin{array}{l}\text { MEDİCINEAND } \\
\text { TEXTILLE }\end{array}$} \\
\hline Hash (capsule) & 458360 & 21436 & 299217 & 16550 & 65.28 & 72.21 \\
\hline Cotton (massive) & 6846650 & 2357892 & 4160098 & 2100000 & 60.76 & 89.06 \\
\hline Cotton (fiber) & 6846650 & 914404 & 4160098 & 756000 & 60.76 & 82.68 \\
\hline
\end{tabular}

Source: TUIK and FAO

Although Turkey is world's cereal central, it imports cereal from some countries. These countries which Turkey imported cereal in 2016 were Russia, USA, Netherlands, Germany, France, Bulgaria, Portugal, Spain, Mexico, Kazakhstan, and Ukraine (Table 6), (Anonymous, 20181).

\section{Developments in Animal and Animal Products' Production}

Due to large pasture areas (14 617 thousand hectares), and mountainous and rugged structure (especially east and southeast regions), Turkey is a suitable country for animal husbandry. According to the data of 2016, Turkey's total animal presence was 41329232 (Table 7). But, because the number 
of animals wasn't at a sufficient level, Turkey had to import the farm animals (Anonymous, 2108m). For instance, in 2016, 494301 bovine animal were imported, and it was paid 587422897 USD for import (Anonymous, 2018ö). This matter reveals that animal husbandry investments should be increased.

Table 6. Cereal import (2016)

\begin{tabular}{|c|c|c|c|}
\hline Crops & & (1000 tons) & $(1000 \$)$ \\
\hline Wheat & & 4226 & 892409 \\
\hline Barley & & 40 & 9807 \\
\hline Corn & & 535 & 128639 \\
\hline Paddy & & 202 & 73731 \\
\hline Lentil & & 289 & 242 \\
\hline Cotton & & 793 & 1192 \\
\hline Oil seed & & 2654 & 1270 \\
\hline Soybean & & 1936 & 788 \\
\hline Sunflower & oil & 620 & 863 \\
\hline (raw) & & 1386 & 384 \\
\hline Pulp & & & \\
\hline
\end{tabular}

Source: TUIK and The Ministry of Agriculture and Forestry

Table 7. The number of animals

\begin{tabular}{|c|c|c|c|}
\hline & 2001 & 2016 & Index \\
\hline Genus & (head) & (head) & $(2001=100)$ \\
\hline Cattle (native) & 4074000 & 1733292 & 42.54 \\
\hline Cattle (culture) & 1854000 & 6588527 & 355.37 \\
\hline Cattle (hybrid) & 4620000 & 5758336 & 124.64 \\
\hline Mandate & 138000 & 142073 & 102.95 \\
\hline $\begin{array}{ll}\begin{array}{l}\text { Total } \\
\text { animal }\end{array} & \text { bovine } \\
\end{array}$ & 10686000 & 14222228 & 133.09 \\
\hline Sheep (merino) & 759000 & 2151264 & 283.43 \\
\hline Sheep (native) & 26213000 & 28832669 & 109.99 \\
\hline Goat (hairy) & 6676000 & 10137534 & 151.85 \\
\hline Goat (mohair) & 346000 & 207765 & 60.05 \\
\hline Total ovine & 33994000 & 41329232 & 121.58 \\
\hline
\end{tabular}

Source: TUIK

In Table 8, developments in animal products' production were given (Anonymous, 2018n). In 2001, while red meat production was 435778 tons, in 2016, it was 1173042 tons. But, because red meat production wasn't enough to satisfy interior consumption, production deficiency was satisfied by imports. For example, in 2016, 4066 tons of red meat was imported, and 29464983 USD was paid for import (Anonymous, 2018ö). These figures reveals that animal products' production was insufficient, and its production should be increased.

Table 8. Animal products' production

\begin{tabular}{lrrr}
\hline Livestock products & \multicolumn{1}{c}{2001} & 2016 & Index \\
\cline { 2 - 4 } & \multicolumn{1}{c}{ (tons) } & (tons) & $(2001=100)$ \\
\hline Red meat & 435778 & 1173042 & 269 \\
Milk & 9495550 & 18489161 & 195 \\
Chicken meat & 614745 & 1879018 & 306 \\
Chicken egg (number) & 10575046000 & 18097605000 & 171 \\
Honey & 60190 & 105727 & 176 \\
\hline
\end{tabular}

Source: TUIK 
For period 2001-2016, the agricultural area of Turkey decreased by $6.32 \%$. The size of the surface area of Yalova is $850 \mathrm{~km}^{2}$, dir. In other words, in the last 15 years, the agriculture land as much as 30 times of the size of the surface area of Yalova province was pulled out of the agriculture. This shows that urgent measures should be taken to protect the agricultural lands.

Turkey is ranked $30^{\text {th }}$ in the entire world with a total of 38379572 hectares of the agricultural land that it has. Total surface area of the Netherlands that is a country of European Union is 41526 sq. $\mathrm{km}$. Its surface area is a one-nineteenth of total agricultural land of Turkey. Its total agricultural land is 18.391 sq. km and one-twentieth that of Turkey's. However, value of its agricultural export was 55 billion USD and was 3.5 times more than Turkey's (Anonymous, 20180). Its total agricultural foreign trade was also much more than that of Turkey. According to the data of 2014, while the Netherland's total agricultural foreign trade was 176 billion USD that of Turkey was 34.3 billion USD (Erol, 2014). In the same year, while the Netherland's agricultural export value was 90 billion USD, that of Turkey was 18 billion USD (Anonymous, 2018r). According to the data of 2012, wheat yield of the Netherlands was $858 \mathrm{~kg}$ decare $^{-1}$, and that of Turkey was $267 \mathrm{~kg}$ decare $^{-1}$ (Anonymous, 2012).

Advanced technologies used in agriculture made the Netherlands as second country exporting the most important agricultural product of Europe. When Turkey's and the Netherlands' agriculture were compared with each other, the importance of the science and the technology has shown up once again. When examined in this respect, there is a need for permanent and supportive arguments so that Turkey can use its agricultural power in real meaning. Therefore, without spending any time, science and technology in the agriculture must be transported to extreme points farmed.

In the same way, though rural population of the Netherlands have declined, its amount of the agricultural land has remained the same. Both rural population and amount of the agricultural land of Turkey decreased (Anonymous, 2018p).

\section{CONCLUSION}

Agricultural sector is one of necessary sectors for socio-economic development of Turkey. Since establishment of the Republic of Turkey, the agricultural sector has taken on important tasks both in economic and social life. Therefore, In Turkey, it isn't possible to neglect the agricultural sector. Therefore, it is useful to take into consideration the following points for agricultural sector.

Irregular rural migrations should be prevented and particularly young population should be brought in the agriculture. Therefore, rural areas should be encouraged in suitable methods and the agricultural sector should be worked up into an attractive and respectable sector.

In the period examined, it was seen there was a significant decrease in amount of the agricultural lands. "Law on Soil Protection and Agricultural Lands' Usage", which was put into force in 2005, should be in full implemented.

In the study, it was determined that total fallow area was too much. When based on 2016, 20.6\% of total field land was fallowed. Thanks to suitable alternation system, both fallowed lands will be used and share of the agriculture in economy will increase.

Effective constructive policies about the agriculture should be developed. Among these policies, it is that all inputs including pesticides, veterinary medicines and its services and animal husbandry should be included in the scope of subsidy.

Agricultural price support policies should be product, production and farmer-focused for ensuring revenue stability. 
Training and broadcast studies in rural should be conducted and farmers should be informed on advanced agricultural technology.

The share of the agricultural sector in total employment, gross domestic product and export should be increased. Therefore, high-class and new product varieties should be selected in accordance with demands of foreign market.

Encouragements and credits for the developing of animal husbandry should be made attractive, meadow and pasture lands should be used the best and sowing areas of forage plants should be expanded.

\section{REFERENCES}

Açıl AF, 1984. Economy I (Genel Economy). Department of Agricultural Economics Ankara University Faculty of Agriculture No.: 898, p352, Ankara.

Açıl AF, Demirci R, 1984. Agricultural Economics Courses. Department of Agricultural Economics Ankara University Faculty of Agriculture No.: 880, p372, Ankara.

Anonymous, 2012. https://www.tzob.org.tr/basin-odasi/haberler/bugdayda-verim-dunya-ortalamasinin-altinda (Date of access: 15.09.2019).

Anonymous, 2018a,b,c,d,h,1,k,j,m,n,o,s. http://www.tuik.gov.tr/Start.do (Date of access: 08.03.2018). Anonymous, 2018e. http://www.mevzuat.gov.tr/MevzuatMetin/1.5.6360.pdf (Date of access: 12.07.2018).

Anonymous, 2018f. http://www.resmigazete.gov.tr/eskiler/2001/06/20010621.htm\#23 (Date of access: 13.03.2018).

Anonymous, 2018g. http://www.tarim.gov.tr/ (Date of access: 23.06.2018).

Anonymous, 2018k,j. http://www.fao.org/ (Date of access: 12.03.2018).

Anonymous, 20181. http://www.tmo.gov.tr/Upload/Document/hububat/hububatraporu2016.pdf (Date of access: 13.07.2018).

Anonymous, 2018ö. Red Meat Sector 2018 Evaluation Report. http://www.etb.org.tr/ media/raporlar/K\%C4\%B1rm\%C4\%B1z\%C4\%B1\%20Et\%20Sekt\%C3\%B6r\%C3\%BC\%202018\%20Y\% C4\%B11\%C4\%B1\%20De\%C4\%9Ferlendirme\%20Raporu\%20-18.\% 2012.2018.pdf (Date of access:13.09.2019).

Anonymous, 2018p. https://www.ekonomi.gov.tr/portal/faces/home/ disIliskiler /ulkeler /ulke-detay/Hollanda/ html-viewer-ulkeler? (Date of access: 26.08.2018).

Anonymous, 2018r. https://www.ankaratb.org.tr/anasayfa.php (Date of access: 26.08.2018).

Arıkan R, 1999. Economy. Saray Publishing, p251, Ankara.

Cengiz S, Baydur CM, 2010. Migration towards Urban from Rural and Agricultural Productivity: Case of Turkey. Ç.Ü. Journal of Institute of Social Sciences, 19(2): 85-98, Adana.

Çelik K, 2015. Introduction to Macroeconomics. $6^{\text {th }}$ Edition, Celepler Publishing, p282, Trabzon.

Doğan Z, Arslan S, Ayberk NB, 2015. Development and Problems of Agricultural Sector in Turkey: A Historical Outlook. Niğde University Academic Review of Economics and Administrative Sciences, 8(1): 29-41, Niğde.

Erol E, 2014. Structural Analysis of Agricultural Trade of Turkey and Effects of the EU Process.http://www.tarim.gov.tr/ABDGM/Belgeler/\%C4\%B0DAR\%C4\%B0\%20\%C4\%B0\%

C5\%9ELER/Uzmanlik\%20Tez\%20may\%C4\% B1s\%202015/Erdal\% 20Erol.pdf (Date of access: 05.03.2018).

Gürsakal N, 2000. ABC of the Statistics. Marmara Issues, p: 187, Bursa.

Meijerink G, Roza P, 2007. The role of agriculture in economic development. http:// www.boci.wur.nl/UK/Publications/ (Date of access:16.12.2018).

Rehber E, Çetin B, 1998. Agricultural Economics, Uludag University Empowerment Foundation, No.: 134, Vipas, Bursa. 
Şimşek Ş, 2002. Introduction to Business Administrations. Renewed $9^{\text {th }}$ Printing, Günay Ofset, Konya.

Timmer P, 1988. The Agricultural Transformation. https://www.dl.icdst. org/ pdfs/ files/42113e9198211f481089e7bef9849bc7.pdf (Date of access: 14.12.2018).

Uzun AM, 2009. Agricultural Productivity and Situation in Turkey: An Study on Measures for Increasing of Agricultural Productivity. http://sbad. gop. edu.tr/Makale ler/1975179771_2.pdf (Date of access: 15.03.2018).

Ünlüönen K, Tayfun A, 2005. Economy. Nobel Publishing, p295, Ankara.

Vasile AJ, Mihai M, Mirela P, 2017. Transformations of the Romanian agricultural paradigm under domestic economic policy reforms: An analysis during 1960-2011. https://ac.els-cdn.com/S0264837717304155/1s2.0-S0264837717304155-main.pdf?_tid=ab63d6a0-b3e1-11e7-8dee-

00000aab0f27\&acdnat=1508316929_3134c921462 ed0103bdf783a2fb8319f (Date of access: 11.02.2018).

Y1lmaz M, 2015. Change of Rural Population and Its Strata According to Provinces in Turkey (1980-2012). http://dergipark.gov.tr/download/article-file/27061 (Date of access: 13.05.2018).

Y1lmaz H, Demircan V, Dernek Z, 2006. Agricultural Structure, Production and Development Potential of Isparta Province. Journal of The Faculty of Agriculture Süleyman Demirel University, 1(2):1-16, Isparta. 